\title{
GAMBARAN SOSIO BUDAYA GIZI ETNIK MADURA DAN KEJADIAN STUNTING BALITA USIA 24-59 BULAN DI BANGKALAN
}

\author{
Rizki Kurnia Illahi, Lailatul Muniroh \\ Departemen Gizi Kesehatan, Fakultas Kesehatan Masyarakat Universitas Airlangga, Surabaya \\ Email: dona.azzahra@gmail.com
}

\begin{abstract}
ABSTRAK
Stunting masih menjadi permasalahan gizi di Indonesia. Pada tahun 2015 prevalensi stunting di Bangkalan, Madura adalah yang tertinggi di Jawa Timur. Masyarakat Etnik Madura memiliki praktik sosio budaya yang berkaitan dengan gizi. Tujuan penelitian ini adalah untuk mengetahui gambaran sosio budaya gizi Etnik Madura yang berkaitan dengan stunting. Penelitian ini merupakan penelitian deskriptif dengan rancang bangun cross sectional. Penelitian dilakukan di Desa Ujung Piring, Kecamatan Bangkalan, Kabupaten Bangkalan dengan besar sampel 62 balita yang dipilih dengan metode simple random sampling. Status stunting dinilai melalui antropometri dengan indikator tinggi badan menurut umur dan dibandingkan dengan standar WHO-MGRS. Data praktik sosio budaya gizi meliputi saat hamil dan persalinan, saat menyusui dan saat balita, dikumpulkan melalui wawancara. Data dianalisis secara deskriptif. Hasil penelitian menunjukkan bahwa prevalensi stunting pada balita di Desa Ujung Piring sebesar 29\%. Praktik sosio budaya gizi Etnik Madura meliputi praktik sosio budaya gizi pada ibu dan praktik sosio budaya gizi pada balita. Praktik sosio budaya gizi yang kemungkinan berkaitan dengan stunting yaitu pantangan makan ibu hamil, pemberian makanan prelakteal pada bayi baru lahir, bayi tidak memperoleh imunisasi, dan pemberian makanan pendamping ASI dini balita. Disarankan agar ada upaya penurunan kepercayaan pantang makan ibu hamil, mengurangi pemberian makanan prelakteal pada bayi baru lahir, dan cakupan pemberian makanan pendamping ASI dini melalui penyuluhan rutin dengan melibatkan orang tua ibu balita yang menjadi key person dalam komunikasi kesehatan.
\end{abstract}

Kata kunci: balita, Madura, sosio budaya, stunting

\section{ABSTRACT}

Stunting is a nutritional problems in Indonesia. District with the highest prevalence of stunting in East Java in 2015 was Bangkalan. Madurese peoples is known to have socio cultural practices which related to nutrition. This study was aimed to describe socio-cultural aspects of nutrition that related to stunting. This study was a descriptive study with cross sectional design. The study was done in Ujung Piring Village, Bangkalan and the sample size was 62 children who were selected by using simple random sampling technique. Stunting status was assessed through anthropometric indicators according to height for age (H/A) and compared to WHO-MGRS standard. Data on practices of socio culture in nutrition during pregnancy and childbirth, breastfeeding and children under-five, were collected through interviews. Data were analyzed descriptively. The results showed that the prevalence of stunting in children under five in Ujung Piring Village was 29\%. Practices of socio culture in nutrition on Madurese Ethnic including socio culture in nutrition of mother and socio culture in nutrition of toddler. Socio cultural aspect of nutrition which probably related to stunting were food taboo for pregnant women, prelacteal food for newborn, infants did not receive immunization and early giving of complementary feeding. It is suggested to have an effort to decrease food taboo for pregnant women, reduce prelacteal food for newborns, and reduce giving complementary feeding early through counseling involving parent's mothers as the key person in health communication.

Keywords: children under five, Madura, socio-cultural, stunting

\section{PENDAHULUAN}

Stunting merupakan penilaian status gizi berdasarkan indikator panjang badan menurut umur $(\mathrm{PB} / \mathrm{U})$ atau tinggi badan menurut umur
(TB/U) di mana hasil pengukuran antropometri menunjukkan Z-Score <-2 SD sampai dengan -3 SD (pendek/stunted) dan <-3 SD (sangat pendek/severe stunted) (Kemenkes RI, 2013). 
Prevalensi stunting balita di Bangkalan masih tinggi jika dibandingkan prevalensi Jawa Timur. Data Pemantauan Status Gizi (PSG) Provinsi Jawa Timur Tahun 2015 menunjukkan prevalensi balita stunting di Bangkalan adalah yang paling tinggi di Jawa Timur, yaitu sebesar 53,2\% dengan rincian prevalensi balita sangat pendek sebesar 27,4\% dan balita pendek sebesar 25,8\% (Dinkes Prov. Jatim, 2015).

Banyak faktor yang memengaruhi status gizi anak, baik faktor langsung maupun faktor tidak langsung. Budaya merupakan salah satu faktor tidak langsung yang memengaruhi status gizi anak. Budaya merupakan salah satu faktor yang memengaruhi sikap ibu di dalam menjalani masa kehamilannya, menjalani proses persalinan, serta dalam pengasuhan balita.

Budaya, tradisi, atau kebiasaan yang ada dalam masyarakat seperti pantangan makan, dan pola makan yang salah dapat mengakibatkan munculnya masalah gizi terutama bagi balita. Hal ini dapat berdampak terhadap pertumbuhan dan perkembangan balita (Adriani dan Wirjatmadi, 2013).

Budaya yang dimiliki oleh Indonesia sangat kaya dan beragam. Madura merupakan salah satu suku yang kaya akan budaya. Hasil studi pendahuluan, dan data Kemenkes (2012) menunjukkan bahwa terdapat beberapa budaya pada Etnik Madura yang berhubungan dengan kesehatan ibu dan anak. Budaya ini meliputi sosio budaya gizi ibu saat hamil dan persalinan, saat menyusui, dan masa balita. Sosio budaya gizi saat hamil misalnya beberapa pantangan makan bagi ibu hamil. Ibu hamil dilarang makan cumicumi, daging kambing, buah nanas, nangka, durian, serta cabai. Pantangan makan cumi-cumi dipercaya dengan alasan bayi akan sulit dilahirkan karena akan keluar masuk seperti cumi-cumi. Sosio budaya gizi saat menyusui misalnya praktik membuang kolostrum karena dianggap kotor dan sosio budaya gizi masa balita seperti pemberian makanan pendamping ASI dini (sebelum usia enam bulan).

Berdasarkan data Puskesmas Bangkalan tahun 2015, Desa Ujung Piring merupakan desa yang memiliki prevalensi balita stunting paling tinggi di Kecamatan Bangkalan yaitu sebesar
$50,2 \%$. Penelitian ini bertujuan untuk mengetahui gambaran sosio budaya gizi yang berkaitan dengan stunting pada masyarakat Desa Ujung Piring, Bangkalan.

\section{METODE}

Penelitian ini merupakan penelitian deskriptif dengan rancang bangun cross sectional. Penelitian ini dilakukan di Desa Ujung Piring yang merupakan salah satu wilayah kerja Puskesmas Bangkalan.

Sampel penelitian adalah 62 balita yang berusia 24-59 bulan yang memenuhi kriteria: balita berasal dari keluarga penduduk tetap yang ditunjukkan dengan kepemilikan KTP, merupakan keturunan Madura asli, tidak mengalami cacat fisik dan gangguan mental dan dipilih dengan teknik simple random sampling.

Pengumpulan data karakteristik keluarga (pendidikan orang tua, status pekerjaan ibu, pendapatan keluarga, jumlah anggota keluarga), karakteristik balita (umur, jenis kelamin, berat badan lahir, panjang badan lahir), sosio budaya gizi saat hamil dan persalinan, sosio budaya gizi saat menyusui, dan sosio budaya gizi masa balita dilakukan dengan wawancara menggunakan kuesioner kepada ibu balita. Pendidikan orang tua dikategorikan menjadi 3, yaitu rendah jika tamat SMP atau kebawah, menengah jika tamat SMA, dan tinggi jika tamat perguruan tinggi. Pendapatan dikategorikan menjadi 2 menurut UMR Kabupaten Bangkalan. Status gizi balita diukur secara antropometri dengan indeks tinggi badan menurut umur (TB/U). Data tinggi badan balita diperoleh melalui pengukuran tinggi badan menggunakan microtoise.

\section{HASIL DAN PEMBAHASAN}

\section{Karakteristik Keluarga Balita}

Tabel 1 menunjukkan bahwa sebagian besar tingkat pendidikan orang tua balita baik ayah maupun ibu tergolong rendah (tamat SD) yaitu sebesar $62,9 \%$ dan 74,6\%. Dalam penelitian Rahayu dan Khairiyati (2014) di Banjar Baru menunjukkan bahwa tingkat pendidikan ibu memiliki hubungan yang bermakna dengan 
kejadian stunting balita. Pendidikan ibu yang lebih tinggi cenderung berpengaruh positif terhadap tingkat status gizi anak.

Tabel 1. Karakteristik Keluarga Balita

\begin{tabular}{lrc}
\hline \multicolumn{1}{c}{ Karakteristik } & $\mathbf{n}=\mathbf{6 2}$ & $\mathbf{\%}$ \\
\hline Pendidikan Ayah & & \\
$\quad$ Rendah & 39 & 62,9 \\
$\quad$ Menengah & 15 & 24,2 \\
$\quad$ Tinggi & 8 & 12,9 \\
Pendidikan Ibu & & \\
$\quad$ Rendah & 46 & 74,2 \\
$\quad$ Menengah & 10 & 16,1 \\
$\quad$ Tinggi & 6 & 9,7 \\
Status Pekerjaan Ibu & & \\
$\quad$ Bekerja & 13 & 21,0 \\
$\quad$ Tidak Bekerja & 49 & 79,0 \\
Pendapatan Keluarga & & \\
$\quad<$ Rp. 1.414.000 & 34 & 54,8 \\
$\quad$ R Rp. 1.414.000 & 28 & 45,2 \\
Jumlah Anggota Keluarga & & \\
$\quad$ Besar (> 4 orang) & 27 & 43,5 \\
$\quad$ Kecil ( $\leq 4$ orang) & 35 & 56,5 \\
\hline
\end{tabular}

Sebagian besar ibu balita dalam penelitian ini tidak bekerja (ibu rumah tangga) yaitu sebesar $79 \%$. Ibu yang berperan sebagai ibu rumah tangga biasanya memiliki pola asuh terhadap tumbuh kembang balita yang lebih baik daripada ibu yang memiliki pekerjaan di luar rumah, ibu dapat lebih fokus mengasuh anak (Septiana, dkk., 2010)

Sebagian besar $(54,8 \%)$ pendapatan keluarga balita berada di bawah upah minimum kabupaten Bangkalan yaitu kurang dari 1.414 .000 rupiah per bulan. Pendapatan merupakan salah satu indikator yang menentukan status ekonomi. Hasil penelitian di Nepal menunjukkan bahwa indeks kekayaan rumah tangga merupakan faktor risiko stunting (Tiwari, dkk 2014). Skor indeks kesejahteraan rumah tangga yang lebih tinggi berhubungan signifikan dengan peningkatan proteksi kejadian stunting (Gewa dan Nannette, 2012).

Sebagian besar keluarga balita merupakan keluarga kecil (terdiri dari kurang dari atau sama dengan 4 orang) yaitu sebesar $56,6 \%$. Jumlah anggota keluarga mempengaruhi penyediaan dan distribusi pangan dalam keluarga. Kualitas konsumsi pangan semakin buruk pada rumah tangga yang memiliki jumlah anggota keluarga yang relatif banyak (Ariningsih dan Rahman, 2008).

\section{Karakteristik Balita}

Separuh balita berusia antara 24 sampai 35 bulan. Usia merupakan salah satu faktor internal anak yang mempengaruhi kejadian stunting. Hasil penelitian Ramli, dkk. (2009) di Maluku Utara menunjukkan bahwa prevalensi stunting pada anak usia 25-59 bulan lebih tinggi dibandingkan anak usia $0-23$ bulan.

Tabel 2. Karakteristik Balita

\begin{tabular}{lcc}
\hline \multicolumn{1}{c}{ Karakteristik } & $\mathbf{n}=\mathbf{6 2}$ & $\mathbf{\%}$ \\
\hline Umur & & \\
$\quad 24-35$ bulan & 16 & 50,0 \\
36-47 bulan & 15 & 25,8 \\
$\quad 48-59$ bulan & & \\
Jenis Kelamin & 28 & 45,2 \\
$\quad$ Laki-laki & 34 & 54,8 \\
$\quad$ Perempuan & & \\
Berat Badan Lahir & 4 & 6,5 \\
$\quad$ BBLR (<2500 gr) & 58 & 93,5 \\
$\quad$ BB lahir normal $(\geq 2500$ gr) & & \\
Panjang lahir & 6 & 9,7 \\
$\quad$ PB lahir pendek $(<48 \mathrm{~cm})$ & 56 & 90,3 \\
$\quad$ PB lahir normal $(\geq 48 \mathrm{~cm})$ & & \\
Status Gizi TB/U & & \\
$\quad$ Stunting (pendek dan sangat \\
pendek) & 18 & 29,0 \\
$\quad$ Non stunting & & \\
\hline
\end{tabular}

Lebih dari separuh balita $(54,8 \%)$ berjenis kelamin perempuan. Hasil penelitian-penelitian terdahulu tentang hubungan jenis kelamin dan stunting belum menunjukkan konsistensi. Penelitian di Ghana menunjukkan bahwa stunting lebih banyak ditemukan pada anak perempuan dibandingkan laki-laki (Eunice dan Sarah, 2013), namun dalam penelitian Taguri, dkk. (2009) di Libya menunjukkan bahwa prevalensi stunting pada anak laki-laki lebih besar dibanding anak perempuan.

Sebagian besar balita memiliki berat badan dan panjang badan lahir normal yaitu masingmasing 93,5 \% dan 90,3\%. Hasil penelitian Taguri, dkk. (2009), di Libya menunjukkan bahwa berat lahir rendah merupakan salah satu faktor risiko stunting. Hasil penelitian Ernawati, dkk. (2013), di Bogor menunjukkan bahwa ada perbedaan signifikan antara kelompok bayi yang memiliki panjang badan lahir normal dan kelompok bayi yang memiliki panjang badan lahir pendek dengan kejadian stunting. 
Sebesar 29\% balita di Desa Ujung Piring mengalami stunting. Masalah kesehatan masyarakat dianggap berat jika prevalensi pendek sebesar 3039\% (WHO, 2010). Prevalensi stunting balita di Desa Ujung Piring hampir mencapai 30\%, artinya harus ada upaya penurunan prevalensi stunting di wilayah tersebut. Prevalensi stunting balita di Desa Ujung Piring lebih tinggi dibandingkan prevalensi stunting Jawa Timur pada tahun 2015 yaitu sebesar $27,1 \%$.

\section{Sosio Budaya Gizi saat Hamil dan Persalinan}

Sosio budaya gizi saat hamil antara lain pantangan makan cumi-cumi dan ikan pari. Pantangan makan cumi-cumi bagi ibu hamil memiliki alasan dikhawatirkan bayi susah dilahirkan karena akan keluar masuk seperti cumicumi.

Pantangan makan ikan pari mempunyai alasan bentuk ikan pari yang tidak lazim sehingga dikhawatirkan akan berpengaruh terhadap bentuk jasmani anak yang dikandung. Cumi-cumi serta ikan pari merupakan lauk hewani sumber protein. Ibu hamil yang memiliki kepercayaan tabu makanan cumi-cumi dan ikan pari akan berisiko mengalami defisiensi protein. Hasil penelitian longitudinal yang dilakukan oleh Ernawati, dkk. (2013) menunjukkan bahwa asupan protein ibu di masa kehamilan berpengaruh signifikan terhadap status gizi pendek balita.

Kebutuhan gizi saat hamil meningkat sehingga adanya tabu makanan dapat memperparah kurang gizi pada ibu hamil. Kepercayaan pantangan makan yang sangat ketat dapat mengganggu pertumbuhan janin (Sholiha dan Sartika, 2014). Gangguan gizi selama kehamilan dapat mengakibatkan bayi prematur, dan berat badan lahir rendah. Bayi dengan berat badan lahir rendah berhubungan dengan morbiditas dan mortalitas janin dan neonatal, gangguan pertumbuhan, gangguan perkembangan kognitif dan penyakit kronis di kehidupan yang akan datang (Blanc dan Wardlaw, 2005).

Sosio budaya gizi saat hamil yang lain yaitu pantangan makan makanan yang dianggap bersifat panas (daging kambing, buah nanas, buah nangka, cabai dan durian). Pantangan makan daging kambing, nanas, nangka, cabai dan durian
Tabel 3. Distribusi Responden Menurut Sosio Budaya Gizi di Desa Ujung Piring, Bangkalan Tahun 2016

\begin{tabular}{lrc}
\hline \multicolumn{1}{c}{ Sosio Budaya } & n & $\mathbf{\%}$ \\
\hline Saat Hamil dan Persalinan & & \\
$\quad$ Pantangan makanan bersifat panas & 16 & 25,8 \\
Pantangan makan cumi-cumi & 15 & 24,2 \\
Pantangan makan ikan pari & 10 & 16,1 \\
Minum minyak kelapa mulai trimester 3 & 29 & 46,8 \\
Konsumsi jamu & 28 & 45,2 \\
$\quad$ Melahirkan di Bidan & 49 & 79,0 \\
Saat Menyusui & & \\
$\quad$ Praktik membuang kolostrum ASI & 14 & 22,6 \\
Pantangan mengkonsumsi ikan laut & 3 & 4,8 \\
Pantangan mengkonsumsi cabai & 40 & 64,5 \\
$\quad$ Konsumsi jamu & 43 & 69,3 \\
\hline
\end{tabular}

dikarenakan masyarakat beranggapan bahwa buah tersebut bersifat panas dan akan menyebabkan keguguran. Pengelompokan makanan panas dan dingin bukan berasal dari suhu makanan tersebut melainkan datang dari China dan India sebagai penyimbolan suatu makanan (Sholiha dan Sartika, 2014). Daging kambing merupakan lauk sumber protein, sedangkan buah-buahan merupakan sumber vitamin dan serat. Apabila ibu hamil dilarang makan daging dan buah tersebut maka hal ini dapat membatasi asupan gizi ibu hamil. Di sisi lain konsumsi nanas tidak dianjurkan bagi ibu hamil yang usia kandungannya masih muda. Hal ini dikarenakan nanas mengandung enzim bromelin yang dapat menstimulasi produksi prostaglandin yang mengakibatkan kontraksi uterus, sehingga dalam hal ini nanas berperan sebagai induksi alami. (Kamatenesi-Mugisha dan Oryem-Origa, 2007; Sharma, 2010).

Sosio budaya gizi saat hamil yang ditemukan di lokasi penelitian, tidak hanya berupa food taboo, melainkan juga food belief, misalnya anjuran meminum minyak kelapa saat usia hamil trimester 3, dengan tujuan agar tubuh ibu menjadi licin sehingga mempermudah proses persalinan, dan anjuran konsumsi jamu yang bertujuan agar tubuh ibu hamil tetap sehat. Anjuran mengonsumsi minyak kelapa pada trimester III kehamilan, secara ilmiah dapat menambah asupan gizi ibu hamil, bukan memperlancar persalinan sebagaimana yang kepercayaan masyarakat di lokasi penelitian. Virgin Coconut Oil atau minyak kelapa murni mengandung asam lemak rantai sedang yang 
mudah dioksidasi dan dicerna oleh tubuh sehingga penimbunan lemak di dalam tubuh dapat dicegah. Selain itu minyak kelapa murni mengandung antioksidan yang tinggi seperti tokoferol dan betakaroten. Antioksidan ini berfungsi untuk mencegah penuaan dini dan menjaga vitalitas tubuh (Setiaji dan Prayugo, 2006).

Konsumsi jamu bagi ibu hamil di Desa Ujung Piring ini berupa jamu tradisional yang terbuat dari daun-daunan. Tidak diketahui apa jenis daun tersebut. Jamu ini merupakan jamu bubuk yang dibuat dengan cara disangrai. Konsumsi jamu bertujuan untuk menjaga kesehatan ibu hamil.

Penelitian tentang konsumsi obat tradisional dan dampaknya terhadap janin memang belum dibuktikan secara klinis, namun dari penelitian yang dilakukan pada hewan percobaan menunjukkan beberapa tanaman obat yang digunakan sebagai jamu untuk ibu hamil bersifat oksitosik (merangsang uterus), mengakibatkan perdarahan uterus dan usus, kematian janin, dan pertumbuhan janin lambat (Katno, 2006). Oleh karena itu, penggunaan jamu oleh ibu hamil perlu diwaspadai dan diperlukan adanya standarisasi jamu untuk ibu hamil.

Sebesar $79 \%$ responden dalam penelitian ini melakukan persalinan di bidan, sisanya ada yang di rumah sakit maupun dokter. Seluruh responden dalam penelitian ini sudah melakukan proses persalinan di tenaga kesehatan, tidak ada yang melakukan proses persalinan di dukun. Hal ini menunjukkan bahwa responden telah mendapat pelayanan kesehatan yang tepat saat proses persalinan. Melakukan proses persalinan di tenaga kesehatan dapat mendukung terlaksananya praktekpraktek yang meningkatkan kesehatan bayi seperti inisiasi menyusu dini serta imunisasi.

\section{Sosio Budaya Gizi Saat Menyusui}

Sosio budaya gizi saat menyusui antara lain praktik membuang kolostrum ASI. Kolostrum tidak diberikan pada bayi karena dianggap kotor oleh ibu. Seharusnya ibu balita tidak membuang kolostrum. Bayi yang tidak memperoleh kolostrum akan memiliki kekebalan tubuh yang kurang jika dibandingkan bayi yang diberi kolostrum.
Kekebalan tubuh berfungsi sebagai proteksi bayi terhadap penyakit infeksi. Penyakit infeksi berhubungan positif terhadap status gizi balita (Masithah, dkk., 2005). Hal ini menunjukkan bahwa secara tidak langsung pemberian kolostrum pada bayi memiliki dampak terhadap status gizi balita.

Sosio budaya gizi saat menyusui berikutnya adalah adanya pantangan makan tertentu bagi ibu. Terdapat responden yang memiliki pantangan makan ikan laut dan cabai masing-masing sebesar $4,8 \%$ dan $64,5 \%$. Alasan pantangan makan ikan laut adalah dikhawatirkan ASI ibu menjadi amis, sedangkan pantangan makan cabai dikhawatirkan bayi menjadi diare. Pembatasan makanan pada ibu menyebabkan nutrisi ibu kurang terpenuhi. Asupan gizi ibu yang kurang akan berpengaruh terhadap kesehatan dan produksi ASI ibu (Kristiyansari, 2009).

Konsumsi jamu tradisional oleh ibu menyusui ini bertujuan untuk memperlancar keluarnya ASI. Jamu tradisional ini dikonsumsi pasca persalinan sampai dengan 40 hari, namun ada juga yang lebih dari itu. Jamu yang diminum merupakan jamu tradisional yang terbuat dari daun-daunan yang dibuat dengan cara disangrai dan ada pula yang direbus. Tidak diketahui apa jenis daun-daunan yang digunakan. Kebiasaan mengonsumsi jamu tradisional ditemukan pula pada ibu-ibu nifas di Desa Sukajadi, Kecamatan Tamansari, Kabupaten Bogor. Salah satu jamu yang dikonsumsi ibu nifas di Desa Sukajadi adalah jamu galohgor yang terbuat dari daun-daunan, biji-bijian, serta akarakaran. Ibu yang mengonsumsi jamu gendong tersebut memperoleh manfaat kebugaran tubuh, peningkatan produksi ASI dan pemulihan rahim (Dahlianti, dkk., 2005).

\section{Sosio Budaya Gizi Masa Balita}

Gambaran sosio budaya gizi masa balita dapat dilihat pada tabel 4 .

Praktik sosio budaya gizi masa balita yang ditemukan di lokasi penelitian adalah inisiasi menyusu dini, praktik imunisasi bayi baru lahir, pemberian makanan prelakteal pada bayi baru lahir, pemberian makanan pendamping ASI dini 
Tabel 4. Distribusi Responden menurut Sosio Budaya Gizi Masa Balita

\begin{tabular}{llc}
\hline \multicolumn{1}{c}{ Sosial Budaya Masa Balita } & n & \% \\
\hline Inisiasi Menyusu Dini & 53 & 85,5 \\
Praktik Imunisasi bayi baru lahir & 56 & 90,0 \\
$\begin{array}{l}\text { Pemberian makanan prelakteal pada } \\
\text { bayi baru lahir }\end{array}$ & 37 & 59,7 \\
$\begin{array}{l}\text { Pemberian makanan pendamping } \\
\text { ASI sebelum bayi berusia 6 bulan }\end{array}$ & 22 & 35,5 \\
$\begin{array}{l}\text { Pantangan mengonsumsi ikan laut } \\
\text { terlalu banyak }\end{array}$ & 1 & 1,6 \\
\hline
\end{tabular}

(diberikan saat bayi belum berumur 6 bulan), dan pantangan mengonsumsi ikan laut terlalu banyak.

Sebesar $85 \%$ responden dalam penelitian ini telah melakukan inisiasi menyusu dini (IMD) bagi bayi. Hasil penelitian yang dilakukan Minarsih dan Adiningsih Tahun 2012 menunjukkan bahwa ada hubungan antara praktek inisiasi menyusu dini dengan kejadian diare pada bayi usia 0-12 bulan. Diare merupakan salah satu faktor risiko kejadian stunting (Taguri, dkk., 2009). Tingginya presentase responden yang telah melakukan praktek iniasi menyusu dini diharapkan menjadi salah satu upaya mencegah terjadinya stunting pada balita.

Sebesar 90\% responden telah mendapatkan imunisasi dasar saat lahir. Bayi dan balita merupakan kelompok yang paling membutuhkan imunisasi karena mereka sangat peka terhadap penyakit. Selain itu sistem kekebalan tubuh balita masih belum sebaik orang dewasa (Hidayat, 2008). Sistem kekebalan ini membuat balita menjadi tidak mudah sakit. Apabila balita tidak mendapat imunisasi, maka kekebalan tubuh balita akan berkurang dan akan mudah terkena penyakit. Hal ini berdampak tidak langsung dengan kesehatan anak (Supartini, 2002). Hasil penelitian yang dilakukan oleh Taguri, dkk. (2007) menunjukkan bahwa status imunisasi yang tidak lengkap memiliki hubungan yang signifikan dengan kejadian stunting balita.

Sebesar $59,7 \%$ responden memberikan makanan prelakteal kepada bayi yang baru lahir. Makanan prelakteal tersebut berupa madu dan ada pula yang memberikan kelapa muda. Alasan pemberian makanan prelakteal ini agar pencernaan bayi menjadi licin sehingga bayi mudah menerima asupan makanan. Penelitian yang dilakukan di Purwokerto, menyatakan bahwa usia makan pertama merupakan faktor risiko terhadap kejadian stunting pada balita (Meilyasari dan Isnawati, 2014).

Makanan prelakteal ini tidak baik bagi bayi karena makanan prelakteal ini dapat menggantikan kolostrum sebagai makanan yang paling awal untuk bayi. Bayi baru lahir yang diberikan makanan prelakteal berarti tidak menerima ASI eksklusif. Bayi tersebut termasuk dalam kategori menyusu predominan. Menyusu predominan adalah bayi memperoleh ASI dari ibu tetapi bayi tersebut pernah diberi sedikit air, madu, atau makanan/ minuman lain ketika baru lahir dan sebelum ASI keluar (Widodo, 2011). Hasil penelitian Giri, dkk. (2013) menunjukkan bahwa ada hubungan antara pemberian ASI eksklusif dengan status gizi balita usia 6-24 bulan.

Sebesar 35,5\% responden memberikan MPASI secara dini kepada bayi. Makanan pendamping ASI ini berupa pisang halus, atau produk bubur instan. Alasan pemberian makanan pendamping ASI sebelum bayi berusia 6 bulan ini dikarenakan agar bayi tidak rewel. Bayi yang menangis dianggap lapar oleh ibu atau nenek yang mengasuh bayi tersebut sehingga bayi diberi makanan pendamping ASI agar berhenti menangis.

Pemberian makanan yang optimal sangat penting bagi kelangsungan hidup, perkembangan dan pertumbuhan bayi. Makanan pendamping ASI merupakan makanan yang diberikan kepada bayi/ anak untuk memenuhi kebutuhan gizi disamping ASI. MP-ASI mulai diberikan saat bayi berusia enam bulan, karena sebelum usia enam bulan enzim pencernaan dan sistem kekebalan usus bayi belum sempurna sehingga zat tepung dan protein belum dapat dicerna oleh bayi (Najahah, dkk., 2013).

Umur bayi yang semakin bertambah, menyebabkan kebutuhan akan zat gizi semakin meningkat pula dikarenakan proses tumbuh kembang, sedangkan ASI yang dihasilkan ibu kurang memenuhi kebutuhan gizi. MP-ASI merupakan makanan peralihan dari ASI ke makanan keluarga. Pengenalan dan pemberian MP- 
ASI harus dilakukan secara bertahap baik bentuk maupun jumlahnya, sesuai dengan kemampuan pencernaan bayi.

Pemberian MP-ASI merupakan proses transisi dimulainya pemberian makanan khusus selain ASI secara bertahap jenis, jumlah, frekuensi maupun tekstur dan kosistensinya sampai seluruh kebutuhan gizi anak dipenuhi oleh makanan keluarga. Jenis MP-ASI ada dua yaitu MP-ASI yang dibuat secara khusus baik buatan rumah tangga atau pabrik.

Jenis maupun jumlah MP-ASI yang tepat diberikan secara bertahap sesuai dengan usia anak. Risiko terkena penyakit infeksi akibat pemberian MP-ASI terlalu dini disebabkan karena usus yang belum siap menerima makanan serta kebersihan yang kurang (Meilyasari dan Isnawati, 2014). Penelitian yang dilakukan oleh Najahah, dkk. (2013) yang menyatakan bahwa balita yang diberi MP-ASI dini (saat bayi belum berusia enam bulan) memiliki resiko 7,4 kali mengalami stunting dibanding balita yang memperoleh MP-ASI sesuai yaitu mulai usia enam bulan.

Sebesar 1,6\% responden memiliki pantangan makan ikan laut terlalu banyak bagi balita. Alasan pantangan ini karena dikhawatirkan balita akan mengalami cacingan. Padahal ikan laut merupakan lauk sumber protein dan memiliki harga terjangkau. Adanya pembatasan makan ikan laut ini dapat mengurangi asupan protein balita. Penelitian yang dilakukan Anshori (2013) di Kecamatan Semarang Timur menunjukkan bahwa asupan protein kurang merupakan faktor risiko kejadian stunting balita.

\section{KESIMPULAN DAN SARAN}

Sosio budaya gizi Etnik Madura yang dapat mengakibatkan balita berisiko mengalami stunting antara lain pantangan makan bagi ibu hamil, anak tidak memperoleh imunisasi, pemberian makanan prelakteal pada bayi baru lahir, dan pemberian makanan pendamping ASI dini (sebelum bayi berusia 6 bulan).

Disarankan kepada pihak terkait agar ada upaya penurunan kepercayaan pantang makan ibu hamil, mengurangi pemberian makanan prelakteal pada bayi baru lahir, dan cakupan pemberian makanan pendamping ASI dini melalui penyuluhan rutin kepada ibu balita yang bekerja sama dengan orang tua ibu balita serta tokoh masyarakat yang menjadi key person dalam komunikasi kesehatan.

\section{DAFTAR PUSTAKA}

Adriani, M., dan Wirjatmadi, B. (2012). Pengantar gizi masyarakat. Jakarta: Kharisma Putra Utama.

Anshori, AH. (2013). Faktor risiko kejadian stunting pada anak usia 12-24 bulan. (Master's thesis, Diponegoro University, Semarang). Diakses dari: http://eprints.undip.ac.id/41855/1/.

Ariningsih, E., Rachman, H.P.S. (2008). Strategi peningkatan ketahanan pangan rumah tangga rawan pangan. Analisis Kebijakan Pertanian, 6(3), 239-255. Diakses dari: http://pse.litbang. pertanian.go.id/ind/pdffiles/ART6-3c.pdf.

Blanc, A.K., Wardlaw T. (2005). Monitoring low birth weights and evaluation of international estimates an an updated estimation procedure. Bulletin WHO, 83(3), 178-85. doi: 10.1590/ S0042-96862005000300010.

Dahlianti R., Nasoetion, A, dan Roosita K. (2005). Keragaan perawatan kesehatan masa nifas, pola konsumsi jamu tradisional dan pengaruhnya pada ibu nifas di Desa Sukajadi, Kecamatan Tamansari, Kabupaten Bogor. Jurnal, Media Gizi dan Keluarga, 29(2), 55-65. Diakses dari: http://repository.ipb.ac.id/bitstream/ handle/123456789/41879/KERAGAAN\%20 PERAWATAN\%20KESEHATAN-\%20vol\%20 29\%20no2.pdf;jsessionid=D626CA0686B956 D50D973A4A8B1CC318? sequence $=1$.

Dinas Kesehatan Provinsi Jawa Timur. (2015). Pemantauan status gizi. Dinkes Prov. Jatim. Surabaya.

Ernawati, F., Rosmalina, Y., Permanasari, Y. (2013). Pengaruh asupan protein ibu hamil dan panjang badan bayi lahir terhadap kejadian stunting pada anak usia 12 bulan di Kabupaten Bogor. Jurnal Penelitian Gizi dan Makanan, 36(1), 1-11. Diakses dari: http://ejournal.litbang.depkes. go.id/index.php/pgm/article/view/3388.

Eunice, A., dan Sarah, D. (2013). An assestment of nutritional status of under five children in four district in the central religion of Ghana. Asian Journal of Agriculture and Rural Development, 3, 851-860. Diakses dari: http://ageconsearch. umn.edu/handle/198311.

Gewa, C, dan Nannette, Y. (2012). Undernutrition among Kenyan children: Contribution of child, maternal, and household factors. Public 
Health Nutrition, 15(6), 29-38. doi: 10.1017/ S136898001100245X. Diakses dari: http:// www.ncbi.nlm.nih.gov/pubmed/22107729.

Giri, M.K.W., Muliarta, I.W., Wahyuni, N.P.D. (2013). Hubungan pemberian asi eksklusif dengan status gizi balita usia 6-24 bulan di Kampung Kajanan, Buleleng. Jurnal Sains dan Teknologi, 2(1), 184-192. Diakses dari: http:// ejournal.undiksha.ac.id/index.php/JST/article/ viewFile/1423.

Hidayat, AAA. (2008). Pengantar ilmu kesehatan anak untuk pendidikan kebidanan. Jakarta: Salemba Medika.

Kamatenesi-Mugisha, M. dan Oryem-Origa, H. (2007). Medicinal plants used to induce labour during childbirth in Western Uganda. Journal Etnopharmacho, 109(1),1-9.doi: 10.1016/j. jep.2006.06.011.

Katno S.P. (2006). Tingkat manfaat dan keamanan tanaman obat dan obat tradisional. Yogyakarta: Balai Penelitian Tanaman Obat Tawangmangu Depkes RI .Diakses dari: http://perpustakaan. depkes.go.id:8180/bitstream/123456789/833/4/ BK2008-G105.pdf.

Kemenkes RI. (2012). Buku seri etnografi kesehatan ibu dan anak etnik Madura. Jakarta: Kanisius.

Kemenkes RI. (2013). Riset kesehatan dasar 2013. Jakarta: Badan Penelitian dan Pengembangan Kesehatan, Kementerian Kesehatan RI.

Kristiyansari, W. (2009). ASI, menyusui \& sadari. Yogyakarta:Muha Medika.

Masithah, T., Soekirman, dan D, Martianto. (2005). Hubungan pola asuh makan dan kesehatan dengan status gizi anak batita di Desa Mulya Harja. Media Gizi Keluarga, 29(2), 2939. Diakses dari: http://repository.ipb.ac.id/ bitstream/.

Meilyasari F, dan M.Isnawati. (2014). Faktor risiko kejadian stunting pada balita usia 12 bulan Di Desa Purwokerto Kecamatan Patebon, Kabupaten Kendal. Journal of Nutrition College, 3(2), 16-25. Diakses dari: http://download. portalgaruda.org/article.php?article.

Minarsih dan Adiningsih, S. (2012). Hubungan praktek inisiasi menyusu dini dengan kejadian diare pada bayi umur 0-12 bulan. Media Gizi Indonesia, 9 (1), 6-12. Diakses dari: http:// journal.unair.ac.id/.

Najahah I, KT Adhi, GNI Pinatih. (2013). Faktor risiko balita stunting usia $12-36$ bulan di
Puskesmas Dasan Agung, Mataram, Provinsi Nusa Tenggara Barat. Public Health and Preventive Medicine Archive, 1(2), 134-141. Diakses dari: http://download.portalgaruda. org/article.

Rahayu, A., Khairiyati, L. (2014). Risiko pendidikan ibu terhadap kejadian stunting pada anak 6-23 bulan. Penel Gizi Makan, 37(2), 129-136. Diakses dari: http://ejournal.litbang.depkes. go.id/index.php/pgm/article/view/4016/3833

Ramli, Agho, K.E., Inder, K.J., Bowe, S.J., Jacobs, J., dan Dibley, M.J. (2009). Prevalence and risk factors for stunting and severe stunting among under fives in North Maluku Province of Indonesia. BMC Pediatric, 9(64), 1-10. doi:10.1186/1471-2431-9-64

Setiaji, B. dan S. Prayugo. (2006). Membuat virgin coconut oil berkualitas tinggi. Jakarta: Penebar Swadaya.

Septiana, R., Djannah, R.S.N., Djamil, M.D. (2010). Hubungan antara pola pemberian makanan pendamping asi dan status gizi balita usia 6-24 bulan di wilayah kerja Puskesmas Gedongtengen Yogyakarta. Jurnal Kesehatan Masyarakat, 4(2), 118-124. Diakses dari: http:// download.portalgaruda.org/article.php?article

Sharma. (2010). Ethnomedicine of Sonapur, Kamrup District, Assam. Journal of Erhnopharmacology, 9(1), 163-165. Diakses dari: http://nopr.niscair. res.in/bitstream

Sholihah, LA. dan Sartika, RAD. (2014). Makanan tabu pada ibu hamil Suku Tengger. Jurnal Kesehatan Masyarakat Nasional, 8(7), 319-324. Diakses dari: http://jurnalkesmas.ui.ac.id/index. php/kesmas/artikel/viewfile/372/371

Supartini, Y. (2002). Buku ajar konsep dasar keperawatan anak. Jakarta: EGC.

Taguri, A.I., Betilmal, S.M. Mahmud, A.M. Ahmed, O. Goulet, P. Galan, dan S. Hercberg. (2009). Risk factors for stunting among under five in Libya. Public Health Nutrition, 12(8), 11411149. DOI: $10.1017 / \mathrm{S} 1368980008003716$

Tiwari, R., Ausman, L.M., dan Agho, K.E. (2014). Determinant of stunting and severe stunting among under fives: Evidence from The 2011 Nepal Demographic and Health Survey. BMC Pediatric, 14(239), 1-15. DOI: 10.1186.

WHO. (2010). Interpretation guide Nutrition Landscape Information System (NLIS) country profile indicators. Geneva: WHO Press. 
Widodo, Y. (2011). Cakupan pemberian asi eksklusif: akurasi dan interpretasi data survei dan laporan program. Jurnal Persagi,
34(2), 101-108. Diakses dari:http://ejournal. persagi.org/go/index.php/Gizi_Indon/article/ download/106/103 